\title{
Measuring Efficiency of Financial Support in Lifelong Learning System: A Case Study of Ukrainian Regions
}

\section{Giorgi Jikia}

Project manager, DVV International, Georgia country office, Georgia

\section{Anna Vorontsova}

Researcher of the scientific research work; Head of the scientific organization of students, postgraduates and young scientists of ERI BT "UAB”, Sumy State University, Ukraine

\section{Yuriy Petrushenko}

Doctor of Economics, Head of the Department of International Economics, Sumy State University, Ukraine

\begin{abstract}
The development of a quality lifelong learning system (LLLS) provides the possibility of obtaining education of various forms (institutional, individual, dual), levels (pre-school, full secondary education, higher education, adult education, etc.), types (formal, non-formal, informal), from different providers and for the rest of human life. It is this system that will allow an individual not only to realize the potential and improve the quality of life, but also to balance the labor market, will promote socio-economic development of the community, region, country, etc. However, in order for this system to function effectively, it is necessary to introduce changes to the financial mechanism, which would involve the effective use of the available, and the attraction of additional financial resources. This article investigates the essence of the notion of efficiency and analyzes the basic methods for its measurement. Thus, the main goal of this study is to measure the effectiveness of the existing financial support of the lifelong learning system in regions of Ukraine through stochastic frontier analysis. Calculations are made using the computer programme FRONTIER 4.1. This will allow to develop the further action plan and formulate tasks for regional financial policy for the establishment of public-private partnership and the use of a wider range of tools for the financial support of the LLLS.
\end{abstract}

Keywords: lifelong learning system (LLLS), financial support, efficiency, stochastic frontier analysis, production function.

JEL Classification: H52, H75, I20.

(C) The Authors, 2017. This article is published with open access at ARMG Publishing.

\section{Introduction}

According to global trends, society is moving into a new phase of development - the so-called information society or learning society, where information and knowledge are the highest values, and the ability to quickly generate and use them effectively is the basis of a firm competitive advantage for the country and a prerequisite for socio-economic growth. In this regard, there is a change in the economic system on the so-called knowledge-based economy.

According to the World Bank concept, the knowledge-based economy should rest on four pillars:

$>$ educated and skilled workforce capable of continuously improving and adapting their skills for the effective creation and use of knowledge;

$>$ modern and dynamic information infrastructure for the purpose of effective communication, dissemination and processing of information and knowledge;

$>$ effective innovation system consisting of enterprises, research centers, universities, consultants and other organizations that have new knowledge and technologies, use the growing stock of world knowledge, assimilate and adapt them to local needs;

$>$ effective institutional regime of the country and the set of economic incentives it creates should ensure effective mobilization and allocation of resources, stimulate entrepreneurship and promote the creation, dissemination and effective use of knowledge (World Bank, 2007).

As we can see, one of the most important requirements for the education system in the new type of knowledgebased economy is the introduction of the concept of continuing education or lifelong learning. It should be noted separately that in the world community in recent years it is customary to use the term lifelong learning 
instead of lifelong education. This is due to the fact that the focus is shifted from attending educational institutions in order to receive education for an uninterrupted lifelong learning of a man.

This trend in education sector is due to a number of objective social and economic conditions (such as aging of the population, STP and the rapid change in labor market needs, its imbalance, the consequences of the financial and political crisis in most countries of the world, globalization, etc.), and involves changing the financial mechanism of the lifelong learning system (LLLS).

First of all, the state under the conditions of a limited budget and a significant budget load is simply unable to provide such a broad system. That is why, there is a need to analyze the effectiveness of the use of available resources, which will be the basis for further actions by the state for the development of financial support of the LLS. For Ukraine, which is only at an early stage of such changes and has begun reforming the educational sphere, such an analysis is important for understanding the direction of further changes, that has conditioned the relevance of this topic.

Thus, the aim of this article is to assess the effectiveness of the existing financial support of the lifelong learning system in the regions of Ukraine with the help of economic and mathematical tools.

\section{Literature review}

The origin of the concept of lifelong learning reaches 60-70-ies of the twentieth century, which is associated with the development of adult education. However, this paradigm was more widely disseminated in the 1970s, when UNESCO adopted the lifelong learning as one of its own principles for reforming education in the world. The basic documents in this direction have become Faure report «Learning to Be» (Faure, 1972) and Delors report «Learning: The Treasure Within» (Delors et al, 1996). Both documents emphasized the multiple contexts of learning and firmly linked the concept to the economic, social, cultural and environmental challenges that societies and communities face (Yang \& Valdes-Cotera, 2011).

One of the important UNESCO divisions is the Institute for Lifelong Learning, which primarily promotes and supports lifelong learning with an emphasis on adult education, lifelong learning, literacy and non-formal basic education. It pays particular attention to the principle of justice for groups in disadvantaged and conflictaffected areas and countries. Fundamental steps in these areas were made in 2009, when at the Sixth International Conference on Adult Education (CONFINTEA VI) in Belem, Brazil, it was attempted to harmonize adult education with the national development strategies of 144 participating countries. On the basis of this event, the Belém Framework for Action (BFA) (UNESCO Institute for Lifelong Learning, 2010) has been developed, which contains a series of recommendations on improving adult literacy, the implementation, management and financing the adult education and monitoring for their compliance. In addition, the Institute for Lifelong Learning regularly publishes the Global Report on Adult Learning and Education (GRALE) (UNESCO Institute for Lifelong Learning, 2010, 2013, 2016), which monitors the development of adult education in UNESCO Member States, its implementation at the legislative level, etc.

In the European Union, the promotion of the concept of lifelong learning was intensified in 2000, which is associated with Lisbon Process (Lisbon European Council, 2000) and, respectively, the development of the Memorandum on lifelong learning (European Commission, 2000). In our opinion, such a non-governmental organization as European Association for the Education of Adults should also be noted, which also significantly supports the extension of lifelong education in general and adult education as well. It collaborates with many other organizations on informational and organizational support for promoting the concept of adult education and lifelong learning. It was with their support that 2017 was proclaimed the year of adult education in Europe and official publication of Manifesto for adult learning in the 21st century (European Association for the Education of Adults, 2016).

In addition, information and partly financial support for the development of lifelong learning system can be provided by the Council of Europe, the OECD, the World Bank, governments of individual countries (for example, the Ministry of Economic Cooperation and Development of Germany provides financial support to non-governmental organizations for the development of adult education in Ukraine, Moldova, Belarus, etc.), as well as other international institutions of civil society.

Separately, it should be noted that the concept of lifelong learning is inextricably linked to the concept of sustainable development. Its roots are related to the Education for All (EFA) movement, which raised the issue of the importance of basic education (World Conference on Education for All: Meeting Basic Learning Needs, 1990) and reflected in the Millennium Development Goals. This was the basis for the establishment of the UN 
Decade of Education for Sustainable Development (UNDESD), reflected in the global SDG adopted by the UN General Assembly: "Goal 4: Ensure inclusive and quality education for all and promote lifelong learning" (UN General Assembly, 2015). However, besides this, lifelong learning is closely interrelated with other constituents of the concept of sustainable development:

$>$ Planet:

1) education is the most effective means of reducing birth rates;

2) education in the field of ecology can increase the spread of "green knowledge";

3) education is crucial for ensuring preparedness for the relieving the consequences of natural disasters;

Prosperity:

1) education can increase labor productivity in agriculture;

2) education can provide the skills for green innovation;

3) education reduces poverty;

\section{People:}

1) education reduces gender inequality;

2) education improves health and reduces birth rate;

Place:

1) education helps reduce inequalities in cities, giving people the life skills they need to work;

2) education reduces crime rates in cities;

3) education improves the welfare of cities and makes them green;

Peace:

1) education can contribute to constructive participation in the political life of society;

2) education helps people get access to justice system (UNESCO, 2016).

All this determines xcellent importance and significance of the concept of lifelong learning and the need for each country to introduce an effective mechanism for its functioning.

\section{Theoretical approaches to the concepts of "efficiency" and "effectiveness"}

First of all, we propose to consider the economic content of the concepts of "efficiency", "effectiveness" and their derivatives, because in the scientific literature there are many different views on their essence, including their identification.

The basis for these definitions is the word "effect" (from Latin "effectus" - execution, action), which according to the Ukrainian explanatory dictionary is interpreted as "the result, consequence of any causes, forces, actions, measures" (Busel, 2005), which can have different expressions. As part of our study, we are interested in two of its main types: economic and social effects.

According to the financial and economic dictionary, the term "economic effect" is understood as "the effectiveness of economic activity, the implementation of economic programmes and measures, characterized by the ratio of the resulting economic effect (result) to the cost of resources that led to the receipt of this result" (Zahorodnii, Vozniuk, 2007).

Instead, under the social effect it is meant “... the result of promoting one or another socially significant problem ..." (Marenychenko, 2013) both at the level of the individual and at the level of society as a whole, characterized by the improvement of social indicators, such as quality of life, health, the state of the labor market (employment growth and unemployment reduction), improving the quality of education and citizenship knowledge, etc.

In turn, the term "efficiency" is considered by scientists as:

the ratio of the result or the effect of any activity and costs, the so-called "result-cost" system (Cherep, Strilets, 2013, Andriichuk, 2005), etc .;

$>$ the ability of the subject to achieve the stated goals, aim (Kutsenko, 2008, Prokofieva, 2012, Surmyn, 2003), etc .;

$>$ the effectiveness, that is, the result of the activity (effect) which a society, enterprise or individual is receiving per unit of resources used (or applied) (Paderyn, 2003).

Thus, some authors identify these concepts. Instead, according to DSTU ISO 9000:2007. (2007), there is a clear distinction between the concepts of "efficiency" and "effectiveness": 
"effectiveness is the degree of implementation of the planned activity and achievement of the planned results;

efficiency is the relation between the achieved result and the resources used".

Thus, conditionally it can be stated that efficiency occurs at the internal level of a particular system, and effectiveness is associated with external processes.

\section{Methodology and data}

As we can see, the concept of "efficiency" is quite multidimensional and complex, that causes the use of various methods and models for its evaluation, among which it is decided to allocate:

- not frontier-based methods - non-limiting methods of efficiency analysis consist in comparison of elements of a sample with average values, which allows to assert about the effectiveness or ineffectiveness of an element (Akhtyrko, Bakun, Blinov, etc., 2005);

$>$ frontier-based methods - limiting methods of analysis, consisting in the fact that there is a certain limit of efficiency, with which the elements of the sample are compared;

$>$ nonparametric (or mathematical) approaches consist in the use of the device of mathematical programming and do not need to define the functional form of the function. Instead, the main drawbacks of this group of methods are the definition of only "technical" efficiency, without taking into account the error vector and the sensitivity to the number of variables in the model (Katkova, 2009);

$>$ parametric (or econometric) approaches consist in establishing the certain function specification (production, cost, revenue or profit function) and allow to take into account the effect on the total statistical noise function, as well as factors, for some reason not included in the model (Akhtyrko, Bakun, Blinov, etc., 2005).

Let us consider in more detail separate components of data of groups of methods of measuring the efficiency in Table 1 .

Table 1. The most common approaches of measuring the efficiency

\begin{tabular}{|c|c|c|}
\hline Approaches & Methods & Brief description \\
\hline \multirow[t]{3}{*}{$\begin{array}{l}\text { Nonparametric } \\
\text { approaches }\end{array}$} & $\begin{array}{l}\text { Data Envelopment } \\
\text { Analysis, DEA }\end{array}$ & $\begin{array}{l}\text { Frontier and linear programming method, assuming no random } \\
\text { mistakes, used to measure technical efficiency. This method uses to } \\
\text { measure the relationship in the system inputs- outputs. }\end{array}$ \\
\hline & $\begin{array}{l}\text { Free Disposal Hull, } \\
\text { FDH }\end{array}$ & $\begin{array}{l}\text { A special configuration of DEA model imposing strong disposability of } \\
\text { inputs and outputs but without the convexity assumption. The shape of } \\
\text { production possibility set is stepwise. }\end{array}$ \\
\hline & $\begin{array}{c}\text { Indexes (for example } \\
\text { productivity index, etc.) }\end{array}$ & $\begin{array}{l}\text { Not frontier-based methods, used to determine changes of indices in } \\
\text { time. They are calculated as the ratio of the sum of the weighted output } \\
\text { variables to the sum of the weighted input variables. }\end{array}$ \\
\hline \multirow[t]{6}{*}{$\begin{array}{l}\text { Parametric } \\
\text { approach }\end{array}$} & $\begin{array}{l}\text { Ordinary Least Squares } \\
\text { - OLS }\end{array}$ & $\begin{array}{l}\text { Not frontier-based method, that allows to calculate and estimate the } \\
\text { average cost or production function for a certain sample on the basis of } \\
\text { a regression model, and also allows to estimate the influence of factors } \\
\text { on the dependent variable, their statistical significance. }\end{array}$ \\
\hline & $\begin{array}{l}\text { Corrected ordinary } \\
\text { least squares - COLS }\end{array}$ & $\begin{array}{l}\text { A special case of the OLS method, which involves shifting the line } \\
\text { towards the best performing company. }\end{array}$ \\
\hline & $\begin{array}{l}\text { Modified ordinary least } \\
\text { squares - MOLS }\end{array}$ & $\begin{array}{l}\text { A special case of the OLS method, which calculates the efficiency for } \\
\text { each sample item, it is more effective for panel data. }\end{array}$ \\
\hline & $\begin{array}{l}\text { Stochastic Frontier } \\
\text { Analysis, SFA }\end{array}$ & $\begin{array}{l}\text { Frontier method, that assumes a presence of random noise and } \\
\text { measurement error, includes outliers and the relationship between the } \\
\text { inputs and outputs. }\end{array}$ \\
\hline & $\begin{array}{l}\text { Distribution-Free } \\
\text { Approach - DFA }\end{array}$ & $\begin{array}{l}\text { Efficiency of each company is assumed to be stable over time, and the } \\
\text { random noise averages out to zero. }\end{array}$ \\
\hline & $\begin{array}{l}\text { Think Frontier } \\
\text { Analysis - TFA }\end{array}$ & $\begin{array}{l}\text { Frontier method, that assumes that inefficiencies differ between the } \\
\text { highest and lowest quartile firms. }\end{array}$ \\
\hline
\end{tabular}

Source: compiled by authors based on Eling, M., Luhnen, M. (2008), Akhtyrko Ie., Bakun O., Blinov A., etc. (2005), Katkova N. V. (2009).

Having compared the main advantages and disadvantages of the methods presented in the table, we decided to use the Stochastic Frontier Analysis (SFA) method to evaluate the efficiency of the financial support of LLLS, which allows us to calculate the limit of the deviation of the actual results from the potentially possible using the method of maximum likelihood estimation. 
It should be noted that the main advantages of the use of Stochastic Frontier Analysis include the multifactorial nature of the model, the comparison of the obtained estimates of efficiency, the objectivity of the methods, the probable approach to measuring the efficiency, as well as the ability to test different hypotheses. In turn, the main drawback is the need for a clear specification of the functional form of external efficiency and the law of distribution of inefficiency. In both cases, the lack of a clear specification is removed by using flexible functional forms and non-trivial laws distributions. (Svechnykova, 2008).

It should be noted that in the form of a specification of the function of SFA the production function was chosen, since the main objective at the regional level is to maximize the results of their activities, including in the educational sphere. Functional forms of the production function was originally developed by Aigner, Lovell, and Schmidt (1977) and also Meeusen, Van den Broeck, (1977) and it can be expressed:

$$
Y_{i}=X_{i} \beta+\left(V_{i}-U_{i}\right), i=1 \ldots N
$$

where $Y_{i}-$ level of output for the $i$-th unit;

$X_{i}-$ vector of inputs for the $i$-th unit;

$\beta-$ unknown parameter vector to be estimated;

$V_{i}-$ error component that represent the symmetric disturbance;

$U_{i}-$ non-negative unobservable random variables associated with the technical inefficiency

The measure of technical efficiency for $i$-th unit in the stochastic frontier model is defined as:

$$
\left\{\begin{array}{l}
E F_{I R F P_{L L E}(i)}=\frac{E\left(Y_{i} \mid U_{i}, X_{i}\right)}{E\left(Y_{i} \mid U_{i}=0, X_{i}\right)} \\
U_{i}=X_{i} \beta+V_{i}-Y_{i}
\end{array}\right.
$$

Proceeding from this formula, the calculation of the level of efficiency is based on the ratio of the actual value of the performance indicator with the indicator which level of inefficiency is zero.

To check the efficiency of the financial support of LLLS, the following information base was formed:

$>$ data: panel data set for 22 regions of Ukraine (except Luhansk and Donetsk regions, AR Crimea - due to lack of data) and the city of Kyiv;

$>$ sources of data: statistical data of State Statistics Service of departments of regional state administrations and territorial divisions of the State Treasury Service of Ukraine over the 2009-2015 period;

$>$ output parameter is: Integral regional indicator of financial support for LLLS (IRFS $L L L S)$, which includes costs of both the public sector (expenditures on education from budgets of different levels, state trust funds) and outside the public sector (expenditures of households, private sector for vocational training of employees and public sector on educational activities);

$>$ input parameters (factor variables) are: Regional lifelong learning index (RLLI) and Regional Human Development Index $(R H D I)$;

additional parameters include general macroeconomic indicators in the region: gross regional product $(G R P)$, the consumer price index $(C P I)$, the level of employment $(E m R)$ and unemployment $(U n R)$ of the population, etc. These parameters determine the frontier of break between the actual and the standardized levels of efficiency.

\section{Results}

First of all, we propose to consider the descriptive statistics for the selected indicators of our model in Table 2.

Table 2. Descriptive statistics for variables in the stochastic frontier production function

\begin{tabular}{|c|c|c|c|c|c|}
\hline Variable & Mean & $\begin{array}{c}\text { Standard } \\
\text { deviation }\end{array}$ & Min & Max & $\begin{array}{c}\text { Unit of } \\
\text { measurement }\end{array}$ \\
\hline$I R F S_{\text {LLLS }}$ & 3,486 & 0,101 & 3,244 & 3,801 & index, units \\
\hline$R L L I$ & 17,876 & 1,087 & 16,407 & 20,714 & index, units \\
\hline$R H D I$ & 3,751 & 0,199 & 3,29 & 4,27 & index, units \\
\hline$G R P$ & 62,747 & 85,374 & 8,484 & 503,715 & UAH billion \\
\hline$C P I$ & 113,257 & 14,842 & 98,8 & 145,8 & percent \\
\hline$E m R$ & 58,133 & 2,602 & 51,6 & 64,9 & percent \\
\hline$U n R$ & 8,639 & 1,617 & 5,2 & 12,7 & percent \\
\hline
\end{tabular}


On average, over the analyzed period of Ukrainian regions, the consumer price index ranged from $98.8 \%$ to $145.5 \%$, indicating a significant increase in prices for all categories of goods (especially as a result of energy prices) and a consequence of the political and economic crisis in the country. The average employment rate of the population in Ukraine amounted to $58.13 \%$ for the population aged $15-70$, which is a rather low indicator and also reflects the crisis trends in the economy (there is an increase in shadow employment). Instead, the level of unemployment varied from 5\% to almost $13 \%$ for the population aged 15-70, but also, in our opinion, does not correspond to reality. There is an imbalance between the supply and demand of the labor force, the growth of unemployed among young people and the duration of unemployment, which aggravate the socioeconomic situation of the country. It is in the context of such tendencies that more effective use of financial resources, especially in the field of education, becomes more relevant.

The stochastic frontier model used in this study for measuring efficiency of financial support in lifelong learning system is estimated using the computer program, FRONTIER 4.1.

This programme provides the creation of an input and an output files, which are the basis for the calculations performed and are standardized (logarithmic) values of the statistical base. In addition, with the help of an instruction file, you can create all the conditions for conducting the SFA, as a type of model and function, the number of cross-data and time periods, the number of observations in the model as a whole, and the number of independent and auxiliary variables. As you can see, this manual allows you to analyze panel data, which was an important condition for choosing exactly this software.

The most traditional and widely used forms of the target function of the model in the stochastic frontier analysis are the Cobb-Douglas production function and its complicated form -Translog production functions.

To determine the functional form of the frontier for our model, it was decided to put forward two hypotheses: $\mathrm{H}_{0}$ - the null hypotheses (the type of function is Cobb-Douglas), $\mathrm{H}_{1}$ - the alternative hypothesis (the type of function is translogarithmic). As a hypothesis testing method, the maximum likelihood ratio test or the "simple model versus more complex model" test, which is widely used among scholars in similar studies (Fulginiti, Perrin, Bingxin, 2004), has been applied. Let us compare the test results in Table 3.

Table 3. Hypothesis testing of the functional form in the stochastic frontier function

\begin{tabular}{|l|c|c|}
\hline \multicolumn{1}{|c|}{ Indicator } & $\mathrm{H}_{0}$ & $\mathrm{H}_{1}$ \\
\hline Functional form of function & Cobb-Douglas & Translog \\
\hline $\mathrm{L}\left(\mathrm{H}_{0}, \mathrm{H}_{1}\right)-\log$ likelihood function $\rightarrow \max$ & 269,10 & 246,57 \\
\hline $\mathrm{LR}\left(\mathrm{H}_{0}, \mathrm{H}_{1}\right)-$ LR test of the one-sided error $>\chi^{2}$ & 45,05 & - \\
\hline $\mathrm{r}-$ number of restrictions & 6 & 1 \\
\hline$\lambda-$ maximum likelihood test statistics $<\chi^{2}$ & 0,99 & 0,05 \\
\hline$\chi 2-$ Pearson fitting criterion & 11,07 & 38,89 \\
\hline Result & Accepted & Rejected \\
\hline
\end{tabular}

According to Table 3 , we adopt the null hypothesis $\mathrm{H}_{0}$, that is, the functional form of the function will look like Cobb-Douglas and can be described as follows:

$$
\begin{aligned}
& \ln I R F S_{L L L S}=\beta_{0}+\beta_{1} \ln R L L I+\beta_{2} \ln R H D I+\left(V_{i}-U_{i}\right), i=1 \ldots N \\
& U_{i}=\delta_{0}+\delta_{1} \ln G R P+\delta_{2} \ln C P I+\delta_{3} \ln E m R++\delta_{4} \ln U n R
\end{aligned}
$$

According to the results of the stochastic frontier analysis, we obtain the following estimates of the parameters of the model.

Table 4. Estimation of parameters of the Cobb-Douglas model

\begin{tabular}{|c|c|c|}
\hline Model parameter & Coefficient & Standard-error \\
\hline$\beta 0$ & 0,450 & 0,420 \\
\hline$\beta 1$ & 0,894 & 0,147 \\
\hline$\beta 2$ & 0,475 & 0,093 \\
\hline$\delta 0$ & 0,914 & 0,984 \\
\hline$\delta 1$ & $-0,011$ & 0,014 \\
\hline$\delta 2$ & $-0,141$ & 0,048 \\
\hline$\delta 3$ & $-0,030$ & 0,212 \\
\hline$\delta 4$ & 0,153 & 0,030 \\
\hline$\sigma 2$ & 0,003 & 0,000 \\
\hline$\gamma$ & 1,000 & 0,000 \\
\hline
\end{tabular}


Thus, we observe a direct positive relationship between the effectiveness parameter and Regional lifelong learning index $(R L L I)$ and Regional Human Development Index (RHDI).

According to the frontier analysis, the average efficiency of using financial resources for education is $85 \%$, graphic interpretation of results by regions of Ukraine for 2009, 2012 and 2015 is shown in Figure 1.

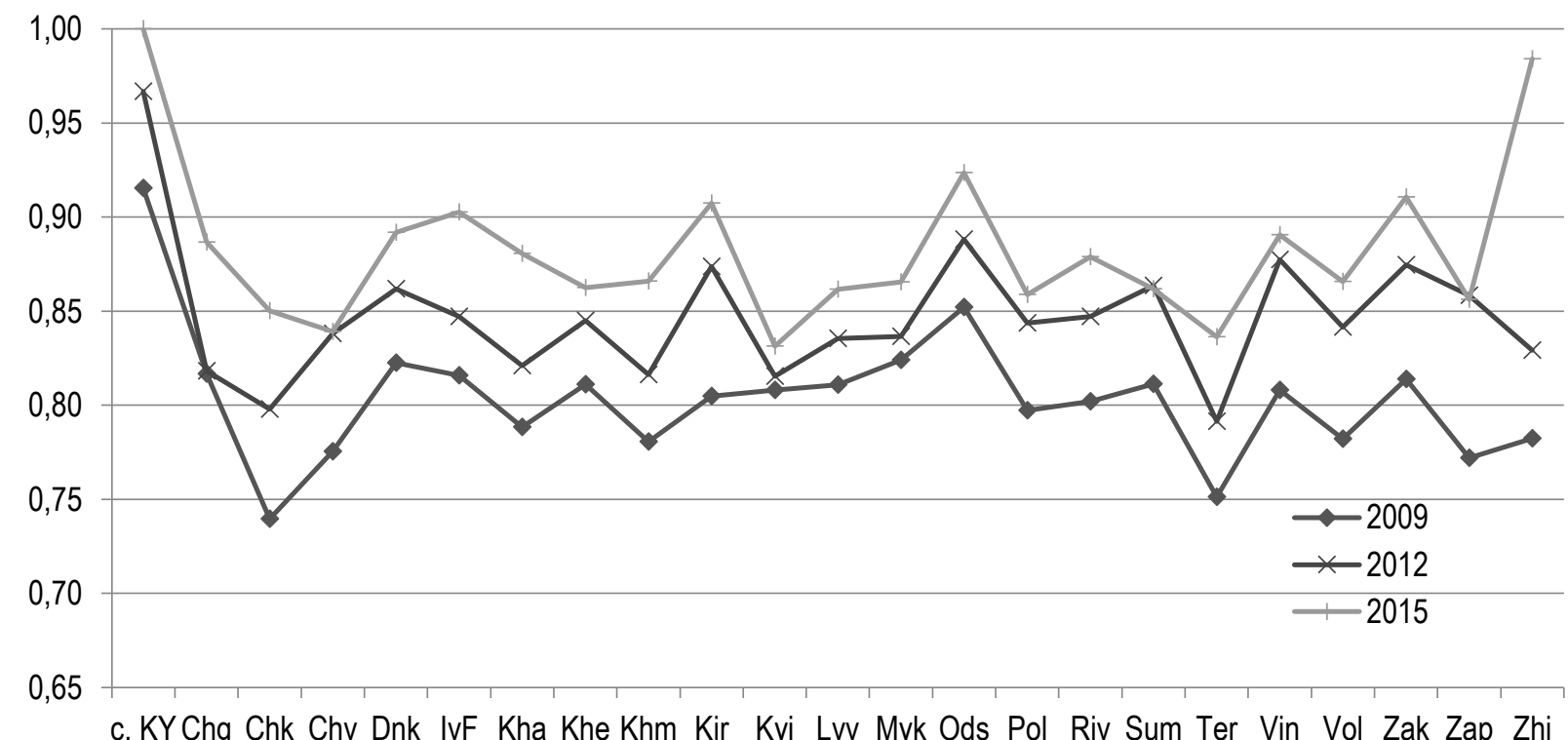

Figure 1. Estimated efficiency of financial support in lifelong learning system in regions of Ukraine in 2009, 2012 and 2015

As you can see, there is an increase in the efficiency of financial support for LLLC for the analyzed period. The highest rates are in Kyiv city, Zhytomyr and Odesa regions, and the lowest ones are in Kyiv, Ternopil and Chernivtsi regions.

\section{Conclusions}

Consequently, the concept of lifelong learning has appeared long ago, but recently thanks to the support of many international organizations (UNESCO, the Council of Europe, the OECD, etc.), it is developing in various countries of the world, including Ukraine. Lifelong learning has been identified as a separate goal of sustainable development, and its interconnection with other components of the sustainable development concept has been identified, after which it can be concluded that it contributes both to personal development and fulfillment, and to economic progress and development, to the solution of many social and environmental problems of the present, social inclusiveness, raising the level of democracy, etc. at the level of the community, region, state and the planet as a whole.

Specially let us focus on the fact that within the framework of the concept of sustainable development, a lot of attention is paid to the mobilization of different levels of stakeholders (including state, local authorities, business, NGOs, territorial communities, etc.) to educational decision-making processes. This approach should be the basis for developing the effective financial mechanism for LLLS, which will ensure the use of more financial instruments.

Within the framework of this research the analysis of the efficiency of use of financial resources in the lifelong learning system in Ukrainian regions was based on the Integral regional indicator of financial support for LLLS (including both state and non-state funding for education), Regional lifelong learning index (RLLI) and Regional Human Development Index (RHDI), corrected towards the general macroeconomic indicators that characterize socio-economic development of the regions. The method of analysis was the stochastic frontier analysis, which with the help of the Cobb-Douglas function, allowed to reveal the relationship between the analyzed indicators and to calculate the limit of the deviation of the actual results from the potentially possible ones. As a result, it was found that the most effective use of available financial resources is in Kyiv city, Zhytomyr and Odessa regions, and the least effective is in Kyiv, Ternopil and Chernivtsi regions. These calculations will be used in further research by authors and will form the basis for the formation of regional strategies for the development of the lifelong learning system and its financial support. 


\section{References}

1. Aigner, D. J., Lovell, C. A. K., Schmidt, P. (1977). Formulation and Estimation of Stochastic Frontier Production Function Models, Journal of Econometrics, 6, 21-37.

2. Akhtyrko, I., Bakun, O., Blinov, A., etc. (2005). Guide to the economic regulation of natural monopolies. International Center for Policy Studiesю Kyiv. 69 p. Available at: http://www.icps.com.ua.

3. Andriichuk, V. H. (2005). Efficiency of activity of agrarian enterprises: theory, methodology, analysis. KNEU. 2nd edition. Kyiv. 292 p.

4. Busel, V. T. (2005). Velykyi tlumachnyi slovnyk suchasnoi ukrainskoi movy: bl. 250000 sl. VTF „Perun”. Irpin. 1728 p.

5. Cherep, A. V., Strilets, Ye. M. (2013). Efficiency as an economic category. Efektyvna ekonomika, 1. Available at: http://nbuv.gov.ua/UJRN/efek_2013_1_26.

6. Dave, R. H. (1976). Foundation of Lifelong Education: Some Methodological Aspects. Studies in Lifelong Education. Hamburg, 344 p.

7. Delors, J. et al. (1996). Learning: the treasure within; report to UNESCO of the International Commission on Education for the 21st Century. Paris, UNESCO.

8. DSTU ISO 9000:2007. (2007). Quality management systems. Basic Terms and Glossary. Available at: http://dbn.at.ua/_ld/11/1128_432_iso9000-1-.pdf.

9. Eling, M., Luhnen, M. (2008). Frontier Efficiency Methodologies to Measure Performance in the Insurance Industry: Overview and New Empirical Evidence. University of St. Gallen. Working Papers on Risk Management and Insurance. 56. Available at: https://ssrn.com/abstract $=1237662$ or http://dx.doi.org/10.2139/ssrn.1237662.

10.European Association for the Education of Adults. (2016). Manifesto for Adult Learning in the 21st Century. Brussels, European Association for the Education of Adults. 9 p. Available at: http://www.eaea.org/media/policy-advocacy/manifesto/manifesto.pdf.

11.European Commission. (2000). Memorandum on lifelong learning. [online] Available at: http://arhiv.acs.si/dokumenti/Memorandum_on_Lifelong_Learning.pdf.

12.Faure, E. et al. (1972). Learning to Be: the world of education today and tomorrow. Paris, UNESCO.

13.Fulginiti, L. E., Perrin, R. K., Bingxin Yu. (2004). Institutions and Agricultural Productivity in Subsaharan Africa. Agricultural Economics, 31, 2-3.

14.Katkova, N. V. (2009). Econometric methods for analyzing the efficiency of enterprises. Visnyk Kharkivskoho NAU im. V.V. Dokuchaieva, 11. 11-19.

15.Kutsenko, A. V. (2008). Organizational and economic mechanism for managing the efficiency of the enterprises of consumer cooperatives in Ukraine: a monograph. RVV PUSKU. Poltava. 205 p.

16.Lisbon European Council. (2000). Precidency Conclusions. [online] Available at: http://www.europarl.europa.eu/summits/lis1_en.htm.

17.Marenychenko, V. V. (2013). Social effect from state regulation of qualitative development of small and medium business. Visnyk Dnipropetrovskoho derzhavnoho ahrarnoho universytetu, 2, 220-223.

18. Meeusen, W., Van den Broeck, J. (1977). Efficiency Estimation from Cobb-Douglas Production Functions With Composed Error. International Economic Review, 18, 435-444.

19.Paderyn, Y. D. (2003). Scientific and practical aspects of increasing the economic efficiency of a modern enterprise. Visnyk Akademii ekonomichnykh nauk Ukrainy, 1. 89-95.

20.Porcelli, F. (2009) Measurement of Technical Efficiency. A Brief Survey on Parametric and NonParametric Techniques. University of Warwick, 11, 1-27. Available at: http://www.warwick.ac.uk/fac/soc/economics/staff/phd_students/porcelli/porcelli_dea_sfm.pdf.

21.Power, C.N., Maclean, R. (2013) Lifelong Learning: Meaning, Challenges, and Opportunities. In: Maclean R., Jagannathan S., Sarvi J. (eds) Skills Development for Inclusive and Sustainable Growth in Developing Asia-Pacific. Technical and Vocational Education and Training: Issues, Concerns and Prospects, vol 19. Springer, Dordrecht.

22.Prokofieva, K. V. (2012). The theoretical essence of the economic category «efficiency of the enterprise». Available at: http://www.pdaa.edu.ua/sites/default/files/nppdaa/6.2/255.pdf.

23.Surmyn, Yu.P. (2003). Theory of systems and systems analysis: a tutorial. MAUP. Kyiv. 368 p.

24.Svechnykova, N. Yu. (2008). Comparative analysis of levels of development of small business in the regions of the Russian Federation and countries with developed market economies. Vestnyk Samarskoho hosudarstvennoho эkonomycheskoho unyversyteta, 8. 84-89.

25.UN General Assembly (2015). Transforming our world : the 2030 Agenda for Sustainable Development. Available at: t: http://www.refworld.org/docid/57b6e3e44.html. 
26.UNESCO Institute for Lifelong Learning (2010). Global report on adult learning and education. $156 \mathrm{p}$. Available at: http://unesdoc.unesco.org/images/0018/001864/186431e.pdf.

27.UNESCO Institute for Lifelong Learning (2010). The Belem Framework for Action: Harnessing the Power and Potential of Adult Learning and Education for a Viable Future. UNESCO: CONFINTEA VI. 38 p. Available at: http://unesdoc.unesco.org/images/0018/001877/187789m.pdf.

28.UNESCO Institute for Lifelong Learning (2013). Second Global Report on Adult Learning and Education (GRALE). $\quad$ Rethinking $\quad$ Literacy. 163 p. http://unesdoc.unesco.org/images/0022/002224/222407E.pdf. - ISBN 978-92-820-1180-5.

29.UNESCO Institute for Lifelong Learning (2016). The third Global Report on Adult Learning and Education (GRALE III). The Impact of Adult Learning and Education on Health and Well-Being; Employment and the Labour Market; and Social, Civic and Community Life. 158 p. Available at: http://unesdoc.unesco.org/images/0024/002459/245913e.pdf. - ISBN: 978-92-820-1213-0.

30.UNESCO. (2016). Community-Based Lifelong Learning and Adult Education: Adult Skills and Competencies for Lifelong Learning. $31 \mathrm{p}$.

31.Vozniuk, H. L., Zahorodnii, A. H. (2007). Financial and Economic Dictionary. Znannia. Kyiv. 1072 p.

32.World Bank (2007). Building Knowledge Economies: Advanced Strategies for Development. WBI Development Studies. Washington, DC: World Bank. Available at: https://openknowledge.worldbank.org/handle/10986/6853.

33.World Bank. (2003). Lifelong Learning in the Global Knowledge Economy: Challenges for Developing Countries. Directions in Development; Washington, DC. Available at: https://openknowledge.worldbank.org/handle/10986/15141 License: CC BY 3.0 IGO.

34.World Conference on Education for All: Meeting Basic Learning Needs. (1990). World declaration on education for all and framework for action to meet basic learning needs adopted by the World Conference on Education for All: Meeting Basic Learning Needs, Jomtien, Thailand. New York, N.Y: Inter-Agency Commission (UNDP, UNESCO, UNICEF, World Bank).

35. Yang, J., Valdes-Cotera, R. (2011). Conceptual Evolution and Policy Developments in Lifelong Learning. Hamburg: UNESCO Institute for Lifelong Learning, pp. 24-39. [online] Available at: http://unesdoc.unesco.org/images/0019/001920/192081e.pdf. 